THE CHOLERA - PRECAUTIONARY MEASURES. To the Editor of THE LANCET.

SrR,-It is daily becoming more evident that the cholera must in future be recognised as an habitual epidemic of this country, and not as a mere extraordinary and occasional visitant; and that medical men must make their preparations to meet it, and, if possible, induce the anthorities and the public to make theirs, no longer occasionally, and by tits and starts, but habitually, and as a regular thing. I have taken opportunities to express this same opinion before, and I must beg leave now emphatically to repeat it, as a matter of some consequence to be borne in mind. We can no longer doubt that, though cholera is an exotic of purely foreign origin, it will in future very often come to us, and become established as a more or less frequent visitor, just as small-pox did in times of old, and just as yellow fever is not improbably about to do.

And respecting the latter disease, look at the accounts from the southern American cities, and say if they do not remind us of the pestilences of the middle ages, driving men to their wits' end to devise strange and unheard of, and yet useless means, to stay the plague, for want of proper attention laving been given to the matter beforehand. Who shall say when that pestilenee may come to us, and become naturalized like the rest? Yet in the careless teaching of our absurdly numerous medical schools, what proper instruction respecting its treatment is given to the student? I fear that in several instances he may look in vain for this, and for some few other things which in common honesty he ought to receive in return for his money.

Let me further suggest, with regard to cholera, a vigilant watchfulness for anything that may help to solve the important question of contagion. In the small cities of Norway, where cholera has raged, every man is personally known, and the progress of any communicable disease can be easily and accurately traced from case to case, and from house to house; and there the medical men, who are extremely intelligent and well-informed, mostly favour the opinion of its contagiousness. And looking at the history of the three advents of cholera into this country, the manner in which on each occasion it advanced, and the places, chiefly those holding communication with infested points, at which it first appeared, and its march, rather along frequented lines of human communication, and among towns and cities, than across country and into solitary districts, it is impossible not to entertain grave doubts whether the theory of its contagiousness be not the true one. It is strange that this should still be an unsettled question, now in the third visitation of the malady. I trust that every fact which may throw light upon the point may be sought out and made public by all who have the opportunity, so that a decisive and truthful opinion may be arrived at.

I am, Sir, your obedient servant,

Burwosd-place, Hyde-park, Oct. 1853. WILLIAM E. C. Nourse.

\section{COMPULSORY VACCINATION.}

To the Editor of THE LANCET.

SIR. - There are three parties affected by the Act of Parliament rendering vaccination compulsory: first, the general practitioner; second, the various private vaccine establishments throughout the country; and third, the public at large-that is to sar, the whole community. These three parties, so far as I come in contact with them, seem to me to be ignorant of the new law altogether. The general practitioner fears the loss of the vaccination of the children of his private patients, in consequence of the names of the parish vaccinators being affixed to the notices supplied by the registrars. The private vaccine establishments fear the loss of the subscriptions, and therefore the loss of their occupation, in consequence of the impression made on the minds of the governors that the government of the country have taken the whole affair into their own hands, and that they are exonerated from any further acts of philanthropy on that score. The community, who are the parties most deeply interested, take no notice of the subject. Now, in my opinion, it ought to be made extensively known, both by the medical and public journals, that the new law does not alter the relative bearing of anything that existed before, more than rendering the act of vaccination compulsory upon parents and guardians; that the interests of private medical practitioners will not be at all affected by it; but, above all, that the governors of private institutions may be stimulated to continue their support in an increased degree, because these institutions will have more work to do, and should they fail from lack of funds, there will be no depôt either for parish surgeons or private practitioners from whence to obtain a fresh supply; and as the conditions which induce small-pox exist at certain times in the atmosphere, the community at large will be the sufferers, and the small-pox will be more rife than ever from want of fresh vaccine matter. I may be here reminded of two things - first, that parish surgeons and private practitioners may keep up a supply them. selves; and, secondly, that in case of running short, they may apply to the National Vaccine Institution. Now, with respect to the first case, I think I can safely affirm-I say it from personal and practical knowledge of the subject, and I say it without offence to those gentlemen-that no parish surgeon or private practitioner can keep up a fresh supply throughout the year, from the simple cause that he does not vaccinate a sufficient number of children; hence the reason why surgeons obtain it through druggists. This is a common custom both in London and in the country. Almost all the practitioners in the country obtain their vaccine matter from the London druggists who subscribe to these private institutions. With respect to the second case, I believe the majority of practitioners will admit that the National Vaccine Institution is unable of itself to afford an adequate supply for the wants of the profession. I make this statement from the number of letters of dissatisfaction which appear-see THE LANCET of last week. Looking, therefore, at the whole bearings of the case, seeing that these institutions neither injure the parish surgeon or private practitioner, because the persons who take advantage of them avoid the one on account of the degradation, and the other on account of the expense. They don't consider them to be charities-they don't feel degraded in going there-and consequently they flock to them in thousands in the course of the year, by which means a good supply is kept up for all England, the colonies, and the greater part of Asia and Africa. Considering all these things, I have no hesitation in stating my belief, that should these private institutions go to the ground from any cause, we shall have the small-pox more rife than ever - we shall have again in this country " the pestilence that walketh in darkness, and the sickness that destroyeth at noon-day," and the late Compulsory Vaccination Act will prove a dead-letter.

I remain, Sir, your obedient servant,

Brunswich-place, City-road, Oct. 20, 1853. R. DAVIS, M.T.

\section{THE NEW VACCINATION ACT.}

To the Editor of THE LANCET.

SIR,-The subject of vaccination being at present before the profession is my apology for troubling you with the following few remarks, which, however humbly they may be expressed, I am convinced are not wanting in truth and justice. I believe blank forms are now being distributed to the members of the profession by the Registrar-General, each form (four or five in number) differing in the information required, with full and authoritative directions for filling up the same by the vaccinator without payment for his advice and trouble-for it is clearly a professional opinion as to the fitness or unfitness of the child for the operation-an opinion too of the most vital importance to the people at large, and which, if not candidly and faithfully given, would completely pervert the object of the measure for the compulsory vaccination of children, and this we are expected to do without remuneration. I feel convinced that the profession will not be so callous of their own interest as to allow this additional injustice to be inflicted upon it, but throw off some of their usual apathy and jealousy of each other, and for once combine and render futile this other attempt to extort from us without compensation the very means of our livelihood-" our knowledge," which is our capital. Without combination all attempts to obtain justice will be useless. The medical men of the various districts have only to be unanimous, and return the forms which they have received whence they came, with a protest against the oppressive nature of the Act-a measure manifestly more despotic than that of a contimental government in compelling bakers to sell their bread at cost price. We are not even offered this.

Really our profession seems to be a sort of reserve force, to be called into operation in aid of their country when others cannot be found except those who are inconsistent enough to demand fair wages for their labour. One injustice will be a natural sequence of another; this was preceded by the certificate of death, and doubtless will be followed by something still more exacting-probably a certificate will be required for everybody who may be necessitated to apply for our aid. 